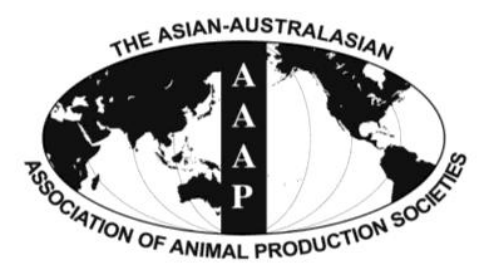

Asian-Aust. J. Anim. Sci.

Vol. 26, No. 3 : 358-365 March 2013

http://dx.doi.org/10.5713/ajas.2012.12507

www.ajas.info

pISSN 101 1-2367 elSSN 1976-5517

\title{
Effects of Synchronicity of Carbohydrate and Protein Degradation on Rumen Fermentation Characteristics and Microbial Protein Synthesis
}

\author{
J. K. Seo, M. H. Kim ${ }^{1}$, J. Y. Yang, H. J. Kim, C. H. Lee ${ }^{2}$, K. H. Kim ${ }^{3}$ and Jong K. Ha* \\ Department of Agriculture Biotechnology, Research Institute for Agriculture and Life Sciences, \\ College of Agriculture and Life Science, Seoul National University, Seoul 151-742, Korea
}

\begin{abstract}
A series of in vitro studies were carried out to determine i) the effects of enzyme and formaldehyde treatment on the degradation characteristics of carbohydrate and protein sources and on the synchronicity of these processes, and ii) the effects of synchronizing carbohydrate and protein supply on rumen fermentation and microbial protein synthesis (MPS) in in vitro experiments. Untreated corn (C) and enzyme-treated corn (EC) were combined with soy bean meal with (ES) and without (S) enzyme treatment or formaldehyde treatment (FS). Six experimental feeds (CS, CES, CFS, ECS, ECES and ECFS) with different synchrony indices were prepared. Highly synchronous diets had the greatest dry matter (DM) digestibility when untreated corn was used. However, the degree of synchronicity did not influence DM digestibility when EC was mixed with various soybean meals. At time points of $12 \mathrm{~h}$ and $24 \mathrm{~h}$ of incubation, EC-containing diets showed lower ammonia-N concentrations than those of C-containing diets, irrespective of the degree of synchronicity, indicating that more efficient utilization of ammonia-N for MPS was achieved by ruminal microorganisms when EC was offered as a carbohydrate source. Within C-containing treatments, the purine base concentration increased as the diets were more synchronized. This effect was not observed when EC was offered. There were significant effects on VFA concentration of both C and S treatments and their interactions. Similar to purine concentrations, total VFA production and individual VFA concentration in the groups containing EC as an energy source was higher than those of other groups (CS, CES and CFS). The results of the present study suggested that the availability of energy or the protein source are the most limiting factors for rumen fermentation and MPS, rather than the degree of synchronicity. (Key Words: Enzyme, Formaldehyde, Synchronicity, Rumen Fermentation, Microbial Protein Synthesis)
\end{abstract}

\section{INTRODUCTION}

Ruminal microbial protein synthesis (MPS) is the most important process in ruminant nitrogen metabolism since MPS not only contribute more than $50 \%$ of the amino acids absorbed in the small intestine, but also have an amino acid composition similar to that of the proteins required for milk synthesis and meat production (NRC, 2000). Ruminal MPS is largely dependent upon the supply of degradable carbohydrates and proteins. When energy from fermentable

\footnotetext{
* Corresponding Author: Jong K. Ha. Tel: +82-2-880-4809, Fax: +82-2-875-8710, E-mail: jongha@snu.ac.kr

${ }^{1}$ Laboratory of Immunology and Hematopoiesis, Department of Comparative Pathobiology; Center for Cancer Research; Purdue University, West Lafayette, IN 47907, USA.

${ }^{2}$ Department of Dairy and Animal Science, Pennsylvania State University, University Park 16802, USA.

3 National Institute of Animal Science, Rural Development Administration, Suwon, 441-707, Korea.

Submitted Sept. 17, 2012; Accepted Nov. 6, 2012; Revised Nov. 23, 2012
}

carbohydrate is supplied in sufficient quantities in the rumen, ruminal microorganisms can capture nitrogen $(\mathrm{N})$ sources such as amino acids or ammonia and convert them to MP (Nocek and Russell, 1988). If, however, the available carbohydrate sources are insufficient, ammonia may accumulate in the rumen and be absorbed into the body and excreted in urine, resulting in inefficient utilization of nitrogen sources. Synchronization is the provision of both rumen-degradable proteins (non-protein nitrogen and rumen degradable true protein) and energy (ruminally fermentable carbohydrate) simultaneously to the rumen (Seo et al., 2010), and has been suggested as one possible solution for improving MPS. Cole et al. (2008) reported that use of synchronized feed has the potential to improve ruminal MPS, $\mathrm{N}$ usage, rumen fermentation and animal performance, and to decrease urinary $\mathrm{N}$ excretion.

A number of previous experiments have evaluated the effects of synchronized feeds on rumen MPS and nitrogen utilization. However, their results have been equivocal. Rotger et al. (2006) used two non-structural carbohydrate 
sources, barley and C, and two protein sources, soy bean (S) and sunflower meal, each having different degradability in the rumen. Synchronized diets containing both rapid (barley-sunflower meal) and slow-fermenting components (C-S meal) had higher OM digestibility, VFA concentration, and MPS than asynchronous diets in vitro. However, in an in vivo trial, synchronization did not seem to affect rumen fermentation characteristics or digestibility (Rotger et al., 2006). A study of the exchange of feed ingredients was intended to differentiate the effects of synchronicity between treatments (Aldrich et al., 1993; Shabi et al., 1998; Rotger et al., 2006; Ichinohe and Fujihara, 2008), but this method could not separate the influence of synchronization from that of the individual feed characteristics (Dewhurst et al., 2000). Therefore, we used the same carbohydrate (C) and protein $(\mathrm{S})$ source to control for the dietary characteristics of each feed component and examine the effects of synchronization in this experiment. The rate of degradation of each feed was adjusted by treating feeds with enzymes and formaldehyde. The objectives of this study were to examine i) the effects of enzyme and formaldehyde treatment on degradation characteristics of carbohydrate and protein sources and synchronicity and ii) the effects of synchronizing carbohydrate and protein supply on rumen fermentation and MPS under in vitro condition.

\section{MATERIAL AND METHODS}

\section{Preparation of experimental diets}

Corn and soybean meal were used as a carbohydrate and a protein source, respectively. All feedstuffs were dried at $60^{\circ} \mathrm{C}$ and ground in a Wiley mill (Arthur H. Thomas, Philadelphia, PA, USA) through a $1 \mathrm{~mm}$ screen prior to enzyme and formaldehyde treatment. Enzymes and formaldehyde were purchased from Sigma Co. Ltd. (Sigma \& Aldrich, St. Louis, USA). Corn was consecutively treated with alcalase $(0.2 \% / \mathrm{wt})$ and $\alpha$-amylase $(1 \% / \mathrm{wt})$ and incubated for $4 \mathrm{~h}$ at $55^{\circ} \mathrm{C}$ to produce enzyme-treated corn (EC). Soybean meal was also treated with alcalase $(0.2 \% / w t)$ and formaldehyde $(0.5 \% / \mathrm{wt})$ to make enzyme-treated meal (ES) and formaldehyde-treated meal (FS). The incubation time and temperature of the $S$ treatment was same as in the $\mathrm{C}$ process. In total, five treated experimental diets were prepared.

\section{In situ experiment}

An in vivo trial was conducted to examine the degradation kinetics of each experimental diet. Ruminal dry matter (DM), organic matter (OM) and crude protein (CP) disappearance rates of each treatment feed were measured using the nylon bag technique as described by Ørskov et al. (1980). Three rumen-cannulated Holstein steers, weighing
$350 \pm 18.77 \mathrm{~kg}$, were used for the in situ experiment. Experimental animals were offered Timothy hay and a commercial concentrate feed (Cargill Agribrand Purina Korea Co. Ltd.) at a ratio of 6:4 twice daily (at 8 am and pm). The total amount of feed offered to animals was $2 \%$ of their body weight. The chemical composition of the commercial concentrate was $87.7 \%$ DM, $14.8 \% \mathrm{CP}, 4.13 \%$ ether extract (EE), $5.22 \%$ ash and $71.5 \%$ total digestible nutrient DM basis. Fresh water and a mineral mixture were available to each animal at all times.

A total of $15 \mathrm{~g}$ of each experimental diet (C, EC, S, ES, FS) was weighed and allotted to nylon bags with a $53 \pm 10$ $\mu \mathrm{m}$ (Bar Diamond, Idaho, USA) pore size. The bags were placed into the ventral sac of the rumen of each Holstein steer through the rumen cannula. The incubation was started at 8:30 am after feeding. All feed samples were incubated for $0,3,6,9,12,24$ and $48 \mathrm{~h}$. After incubation, the bags were removed from the rumen and washed by hand under cold tap water to remove the feed particle attached to the surface of the bags until the rinse water ran clear. Control bags which were not incubated in the rumen $(0 \mathrm{~h})$ were washed in the same way. After washing, all nylon bags were dried at $65^{\circ} \mathrm{C}$ for $48 \mathrm{~h}$ and weighed to estimate the DM residues. The contents of the bags were stored at $4^{\circ} \mathrm{C}$ until chemical analysis.

\section{Evaluation of the characteristics of rumen degradation}

The disappearance rates of $\mathrm{DM}, \mathrm{OM}$ and $\mathrm{CP}$ were calculated as the difference between the weight of the bag contents before and after incubation. The degradability data obtained for each treatment were fitted using PROC NLIN (SAS, 1996) to the following equation (Ørskov and Mcdonald, 1979):

$$
P=a+b\left(1-e^{-c t}\right)
$$

where $\mathrm{P}$ is the degradation rate at time ' $\mathrm{t}$ '; $\mathrm{a}$ is the rapidly soluble fraction; $\mathrm{b}$ is the insoluble but potentially degradable fraction; $c$ is the rate of degradation of fraction $b$; $\mathrm{t}$ is the incubation time.

The effective degradabilities of DM, OM and CP were calculated using the above parameters $(\mathrm{a}, \mathrm{b}, \mathrm{c})$ and a ruminal outflow rate of $0.02,0.05$ and $0.08 \% / \mathrm{h}$ by:

$$
\mathrm{P}=\mathrm{a}+((\mathrm{b} \times \mathrm{c}) /(\mathrm{c}+\mathrm{k}))
$$

Where $\mathrm{P}$ is the effective degradability of $\mathrm{DM}, \mathrm{OM}$ and $\mathrm{CP}$, and $\mathrm{k}$ is the estimated rumen outflow rate $(\% / \mathrm{h})$.

Diet formulation and calculation of synchrony index (SI)

Two carbohydrate samples (C, EC) and three protein samples (S, ES and FS) were prepared as described previously. Carbohydrate and protein samples were mixed 
in a ratio of 0.85:0.15 for a total of six treatment diets (CS, CES, CFS, ECS, ECES and ECFS) for the in vitro experiment to get chemical composition which is similar with commercial concentrated feed. The SI of the diets in the in vitro study was calculated from the degradation kinetics of $\mathrm{OM}$ and $\mathrm{CP}$ of the diet components from the in situ experiments. The SI of $\mathrm{N}$ to $\mathrm{OM}$ was calculated as described by Sinclair et al. (1993).

\section{In vitro experiment}

For the in vitro experiment, rumen fluid was collected and mixed two to three hours after morning feeding from three Holstein steers that were fed with the same feeds as used in in situ experiment. The strained rumen fluid was filtered through eight layers of cheesecloth and transported to the laboratory in a pre-warmed thermo-flask. It was then mixed with artificial saliva (McDougall, 1948) at a ratio of 1:2 under a $\mathrm{CO}_{2}$ stream. Twenty-five milliliters of rumen fluid and buffer mixture was dispensed anaerobically into $50 \mathrm{ml}$ serum bottles, each containing $1 \mathrm{~g}$ of experimental diet. The bottles were then filled with $\mathrm{CO}_{2}$ gas and capped with a rubber stopper. The bottles were incubated for $0,3,6$, 12 and $24 \mathrm{~h}$ in a $39^{\circ} \mathrm{C}$ incubator.

\section{Chemical analysis}

After fermentation, bottle contents were filtered through Whatman No. 541 paper (Fisher Scientific Company, Pittsburgh, PA, USA), and the residues were dried at $65^{\circ} \mathrm{C}$ for $48 \mathrm{~h}$ to measure $\mathrm{DM}$ digestibility. The filtrate was centrifuged at $10,000 \mathrm{~g}$ for $20 \mathrm{~min}$ at $4^{\circ} \mathrm{C}$, and the supernatant was collected to determine $\mathrm{NH}_{3}-\mathrm{N}$ and VFA concentration. The $\mathrm{pH}$ of the filtrate was measured immediately after centrifugation using a $\mathrm{pH}$ meter. After filtering the supernatant through a Millipore filter $(0.22 \mu \mathrm{m}$ pore size), VFA concentration was measured by gas chromatography using a Hewlett Packard 5880A gas chromatograph (Hewlett Packard, Palo Alto, Ca, USA) employing a method described by Erwin (1961). The concentration of $\mathrm{NH}_{3}-\mathrm{N}$ was determined using a modified colorimetric method (Chaney and Marbach, 1962). The in vitro digesta samples were analyzed for purine content (Zinn and Owens, 1986) using HPLC (HP1100, Hewlett Packard, Palo Alto, Ca, USA) according to the modified method (Makkar and Becker, 1999; George et al., 2006) to estimate MPS. All feed components and in situ and in vitro residues were ground in a Wiley mill (Arther H. Thomas, Philadelphia, PA, USA) and analyzed for dry matter (DM), ash, fiber, and nitrogen contents using the Kjeldahl procedure with a Kjeltec (KjeltecTM 2200, Foss Tecator, Sweden) and for EE using diethyl ether with a Soxhlet as described in AOAC (1990). Neutral detergent fiber (NDF) and acid detergent fiber (ADF) were analyzed by the method described by Van Soest et al. (1991) with an Ankom
200 fiber analyzer (Ankom Technology, NY, USA).

\section{Statistical analysis}

The data for the in situ disappearance characteristics of the experimental diets were analyzed using PROC GLM (SAS, 1996). Differences between treatments were considered significant at $\mathrm{p}<0.05$. The data for $\mathrm{DM}$ digestibility, $\mathrm{pH}$ variation, $\mathrm{NH}_{3}-\mathrm{N}, \mathrm{VFA}$, and purine concentrations obtained from in vitro experiments were analyzed using a $2 \times 3$ factorial design using the MIXED procedure (SAS, 1996) with the following model:

$$
Y_{i j}=\mu+\alpha_{i}+\beta_{j}+(\alpha \beta)_{i j}+\varepsilon_{i j}
$$

Where:

$\mathrm{Y}_{\mathrm{ij}}=$ the measured variable

$\mu=$ the overall mean

$\alpha_{i}=$ the effect of carbohydrate sources

$\beta_{\mathrm{j}}=$ the effect of protein sources

$(\alpha \beta)_{\mathrm{ij}}=$ the effect of interaction between carbohydrate and protein sources

$$
\varepsilon_{\mathrm{ij}}=\text { the random error }
$$

The effects of $\mathrm{C}$ treatment, $\mathrm{S}$ treatment and their interaction were considered fixed. Significant differences $(\mathrm{p}<0.05)$ in treatment least square means were reported only if the Tukey-test (SAS, 1996) was also significant $(\mathrm{p}<0.05)$.

\section{RESULTS AND DISCUSSION}

\section{In situ degradation characteristics of feeds}

The chemical compositions of the test feeds are listed in Table 1. Although EC was treated with $\alpha$-amylase and alcalase, the chemical composition of this feed was not influenced by the enzyme treatment. Similarly, treatment of soybean meal with enzyme or formaldehyde did not alter its chemical composition. However, the ruminal degradation characteristics of $\mathrm{C}$ and $\mathrm{S}$ were greatly influenced by enzyme and formaldehyde treatment (Table 2). ES showed higher $(\mathrm{p}<0.05)$ effective degradability of DM, CP, and OM than $S$, but FS had the lowest $(\mathrm{p}<0.05)$ effective degradability of DM, OM, and CP. When $\mathrm{C}$ and $\mathrm{S}$ were

Table 1. Chemical composition of feed ingredients

\begin{tabular}{llrrrrr}
\hline & & \multicolumn{1}{c}{$\mathrm{C}^{1}$} & \multicolumn{1}{c}{$\mathrm{EC}^{1}$} & \multicolumn{1}{c}{$\mathrm{S}^{1}$} & \multicolumn{1}{c}{$\mathrm{ES}^{1}$} & \multicolumn{1}{c}{$\mathrm{FS}^{1}$} \\
\hline $\mathrm{DM}$ & $(\%)$ & 88.56 & 87.93 & 90.59 & 85.45 & 82.75 \\
$\mathrm{OM}$ & $(\% \mathrm{DM})$ & 99.16 & 99.24 & 93.85 & 93.62 & 93.97 \\
$\mathrm{CP}$ & $(\% \mathrm{DM})$ & 8.47 & 9.15 & 54.04 & 54.92 & 54.47 \\
$\mathrm{EE}$ & $(\% \mathrm{DM})$ & 3.97 & 4.15 & 1.49 & 1.47 & 1.78 \\
$\mathrm{NDF}$ & $(\% \mathrm{DM})$ & 12.99 & 13.11 & 14.29 & 14.55 & 14.83 \\
$\mathrm{ADF}$ & $(\% \mathrm{DM})$ & 4.65 & 4.77 & 10.17 & 10.11 & 10.54 \\
\hline
\end{tabular}

${ }^{1} \mathrm{C}=$ Corn, $\mathrm{EC}=$ Enzyme treated corn, $\mathrm{S}=$ Soybean meal, ES = Enzyme treated soybean meal, FS = Formaldehyde treated soybean meal. 
Table 2. Dry matter (DM), crude protein (CP) and organic matter degradation kinetics of the feeds used in the in situ study

\begin{tabular}{|c|c|c|c|c|c|c|}
\hline Items & Feeds & $a^{1}$ & $b^{1}$ & $c^{1}$ & $a+b^{1}$ & $\begin{array}{c}\text { ED } \\
(\mathrm{k}=0.05)^{2}\end{array}$ \\
\hline \multicolumn{7}{|l|}{$\overline{\mathrm{DM}}$} \\
\hline & $\mathrm{C}$ & $11.47^{\mathrm{e}}$ & $78.57^{\mathrm{a}}$ & $0.04^{\mathrm{ab}}$ & $90.05^{\mathrm{a}}$ & $45.54^{\mathrm{c}}$ \\
\hline & $\mathrm{EC}$ & $15.74^{\mathrm{d}}$ & $67.63^{\mathrm{a}}$ & $0.06^{\mathrm{ab}}$ & $83.36^{\mathrm{a}}$ & $51.04^{\mathrm{bc}}$ \\
\hline & S & $25.47^{\mathrm{b}}$ & $53.41^{\mathrm{a}}$ & $0.07^{\mathrm{a}}$ & $78.88^{\mathrm{a}}$ & $56.47^{\mathrm{b}}$ \\
\hline & ES & $31.86^{\mathrm{a}}$ & $60.65^{\mathrm{a}}$ & $0.08^{\mathrm{a}}$ & $92.51^{\mathrm{a}}$ & $68.90^{\mathrm{a}}$ \\
\hline & FS & $17.74^{\mathrm{c}}$ & $82.26^{\mathrm{a}}$ & $0.02^{\mathrm{b}}$ & $100.00^{\mathrm{a}}$ & $37.53^{\mathrm{d}}$ \\
\hline $\mathrm{SEM}^{3}$ & & 1.9518 & 3.8519 & 0.0075 & 3.2533 & 2.8909 \\
\hline \multicolumn{7}{|l|}{$\mathrm{CP}$} \\
\hline & $\mathrm{C}$ & $8.72^{\mathrm{b}}$ & $69.12^{\mathrm{ab}}$ & $0.06^{\mathrm{ab}}$ & $77.84^{\mathrm{a}}$ & $40.22^{\mathrm{b}}$ \\
\hline & $\mathrm{EC}$ & $17.31^{\mathrm{a}}$ & $59.29^{\mathrm{b}}$ & $0.06^{\mathrm{ab}}$ & $76.60^{\mathrm{a}}$ & $45.95^{\mathrm{b}}$ \\
\hline & S & $11.56^{\mathrm{b}}$ & $55.38^{\mathrm{b}}$ & $0.08^{\mathrm{a}}$ & $66.94^{\mathrm{a}}$ & $44.29^{b}$ \\
\hline & ES & $18.75^{\mathrm{a}}$ & $64.22^{\mathrm{ab}}$ & $0.12^{\mathrm{a}}$ & $82.97^{\mathrm{a}}$ & $63.36^{\mathrm{a}}$ \\
\hline & FS & $0.59^{\mathrm{c}}$ & $99.41^{\mathrm{a}}$ & $0.01^{\mathrm{b}}$ & $100.00^{\mathrm{a}}$ & $14.46^{\mathrm{c}}$ \\
\hline $\mathrm{SEM}^{3}$ & & 1.8033 & 5.2152 & 0.011 & 4.4575 & 4.2494 \\
\hline \multicolumn{7}{|l|}{$\mathrm{OM}$} \\
\hline & $\mathrm{C}$ & $11.19^{\mathrm{d}}$ & $78.74^{\mathrm{a}}$ & $0.04^{\mathrm{bc}}$ & $89.93^{\mathrm{a}}$ & $45.16^{\mathrm{c}}$ \\
\hline & $\mathrm{EC}$ & $16.17^{\mathrm{c}}$ & $68.15^{\mathrm{a}}$ & $0.05^{\mathrm{abc}}$ & $84.32^{\mathrm{a}}$ & $51.00^{\mathrm{bc}}$ \\
\hline & $\mathrm{S}$ & $23.68^{\mathrm{b}}$ & $55.82^{\mathrm{a}}$ & $0.07^{\mathrm{ab}}$ & $79.49^{\mathrm{a}}$ & $54.84^{\mathrm{b}}$ \\
\hline & ES & $30.19^{\mathrm{a}}$ & $63.74^{\mathrm{a}}$ & $0.08^{\mathrm{a}}$ & $93.93^{\mathrm{a}}$ & $67.81^{\mathrm{a}}$ \\
\hline & FS & $15.57^{\mathrm{c}}$ & $84.43^{\mathrm{a}}$ & $0.02^{\mathrm{c}}$ & $100.00^{\mathrm{a}}$ & $35.19^{d}$ \\
\hline $\mathrm{SEM}^{3}$ & & 1.8071 & 3.7936 & 0.0068 & 3.2646 & 2.9499 \\
\hline
\end{tabular}

${ }^{1} \mathrm{a}=$ Readily soluble fraction, $\mathrm{b}=$ Insoluble but potentially degradable fraction, $\mathrm{c}=$ Constant rate of degradation of $\mathrm{b}(\% / \mathrm{h})$.

${ }^{2} \mathrm{ED}=$ Effective degradability. Rumen passage rate $(\mathrm{k})$ was considered to $0.05 .{ }^{3} \mathrm{SEM}$ means standard error for means.

${ }_{a, b, c, d, e, ~}$ Indicates that the means are significantly different within different feeds $(\mathrm{p}<0.05)$.

treated with enzyme, their 'a' fraction of DM, OM and CP increased, while the treatment of $\mathrm{S}$ with formaldehyde resulted in a lower $(p<0.05)$ immediately soluble fraction ' $a$ ' and a lower degradation rate of the ' $b$ ' fraction compared with untreated $\mathrm{S}$ (Table 2). The potentially degradable $\mathrm{P}$ fraction $(a+b)$ varied between $66.94 \%$ for $S$ and $100 \%$ for FS. In a number of previously described experiments, the protein source was treated with formaldehyde to protect dietary protein from proteolysis by rumen microorganisms in an effort to increase $\mathrm{N}$ utilization efficiency in the rumen. For instance, Witt et al. (1999b) reported that formaldehyde treatment of $\mathrm{S}$ reduced not only the soluble $\mathrm{N}$ content but also the rate of degradation of the ' $b$ ' fraction. In our experiment, formaldehyde treatment increased the portion of ' $b$ ' fraction but the degradation rate of ' $b$ ' was decreased by chemical treatment. Therefore the ED value of DM, CP and $\mathrm{OM}$ in FS were lower than those of $\mathrm{S}$ significantly $(\mathrm{p}<0.05)$. Eghbali et al. (2011) examined the effects of different treatment methods for canola meal on rumen degradability of CP and DM in in situ studies. The protein fraction was measured based on Cornell Net Carbohydrate and Protein system. Treating with formaldehyde also reduced the protein degradation rate in the rumen in this study. Our results are also consistent with those of Eghbali et al. (2011), who suggested that aldehydes could crosslink with free amino acid groups in feeds so that protein degradability in the rumen might be reduced, but these complexes could be hydrolyzed in the abomasum and small intestine thus enabling protein digestion and absorption in the hindgut.

\section{In vitro experiments}

Exchange of feed ingredients (Herrera-Saldana et al., 1990; Shabi et al., 1998; Rotger et al., 2006) and adjustment of ingredient proportions (Sinclair et al., 1993; Witt et al., 1999a;b; Witt et al., 2000; Richardson et al., 2003; Ichinohe and Fujihara, 2008; Seo et al., 2010) are methods to manipulate the degree of synchronization of carbohydrate and nitrogen release in the rumen. In present experiment, we used the same carbohydrate and protein source treated with enzymes or formaldehyde and mixed at the same ratio to exclude the influence of the characteristics of different feeds on synchronization effects. As mentioned above, 0.85 $\mathrm{g}$ of carbohydrate source $(\mathrm{C}, \mathrm{EC})$ and $0.15 \mathrm{~g}$ of protein source (S, ES, FS) were mixed in order to vary synchronicity in the rumen and were used in in vitro experiment. In total, six kinds of experimental feeds were prepared, and the results of their proximate analysis and their fiber contents are presented in Table 3. All six diets had similar OM, CP, EE, NDF and ADF contents; the average proportion of each was $98.17 \%, 17.55 \%, 3.59 \%$, $13.34 \%$ and $5.77 \%$ of DM, respectively. However, the SI of 
Table 3. Chemical composition and synchrony index of formulated experimental feeds

\begin{tabular}{llrrrrrr}
\hline & & \multicolumn{1}{c}{ CS } & \multicolumn{1}{c}{ CES } & \multicolumn{1}{c}{ CFS } & ECS & ECES & ECFS \\
\hline $\mathrm{DM}$ & $(\%)$ & 88.95 & 87.96 & 87.45 & 88.44 & 87.46 & 86.94 \\
$\mathrm{OM}$ & $(\% \mathrm{DM})$ & 98.14 & 98.10 & 98.17 & 98.21 & 98.16 & 98.23 \\
$\mathrm{CP}$ & $(\% \mathrm{DM})$ & 17.19 & 17.36 & 17.27 & 17.74 & 17.91 & 17.82 \\
$\mathrm{EE}$ & $(\% \mathrm{DM})$ & 3.50 & 3.49 & 3.55 & 3.64 & 3.64 & 3.70 \\
$\mathrm{NDF}$ & $(\% \mathrm{DM})$ & 13.24 & 13.29 & 13.34 & 13.34 & 13.39 & 13.44 \\
$\mathrm{ADF}$ & $(\% \mathrm{DM})$ & 5.71 & 5.69 & 5.78 & 5.80 & 5.79 & 5.87 \\
& & & & & & & \\
$\mathrm{SI}^{1}$ & & 0.85 & 0.95 & 0.71 & 0.93 & 0.80 & 0.72 \\
\hline
\end{tabular}

${ }^{1} \mathrm{SI}=$ synchrony index. SI close to 1.0 means that ruminal release of protein and energy sources is balanced appropriately compared to those having lower SI.

each experimental diet varied between 0.71 in the CFS group and 0.95 in the CES group. Feeds mixed with enzyme-treated carbohydrate or protein source (ECS, CES) had the highest SI, while the groups including formaldehyde treatment group (CFS, ECFS) showed lower $\mathrm{SI}$, which may have been due insufficient $\mathrm{N}$ release of FS in the rumen.

All six experimental diets were used in the in vitro experiment to evaluate the effects of synchronicity on rumen fermentation characteristics and MPS. The in vitro $\mathrm{DM}$ digestibility, $\mathrm{pH}$, and ammonia-N concentration as influenced by different SI are presented in Table 4 . The DM digestibility of all treatments increased as incubation time progressed from $0 \mathrm{~h}$ to $24 \mathrm{~h}$. A significant interaction between $\mathrm{C}$ and $\mathrm{S}$ treatment was detected at $24 \mathrm{~h}$ incubation for DM digestibility $(p<0.01)$. CFS and ECFS with lower SI resulted in lower $(\mathrm{p}<0.01)$ digestibility than those of high and intermediate SI groups at all incubation times, and highly synchronous diets had the greatest $(\mathrm{p}<0.01) \mathrm{DM}$ digestibility within the $\mathrm{C}$ groups. However, the degree of synchronicity did not influence digestibility within the EC groups. The results of the present study suggest that the rapidly fermentable fraction of the diet in the rumen is more important for ruminal digestion than the degree of synchronicity. Herrera-Saldana et al. (1990) also observed that barley-containing diets, which are more rapidly degraded than corn, had higher DM, OM, CP and starch digestibility than corn-based diets, regardless of the synchronicity of the carbohydrate and protein degradation rates. Since we used highly fermentable carbohydrate and protein sources in our experimental diets, the $\mathrm{pH}$ was rapidly dropped after $6 \mathrm{~h}$ of incubation in all treatments. Both treatments of $\mathrm{C}$ and $\mathrm{S}$ influenced the medium $\mathrm{pH}$ at

Table 4. In vitro $\mathrm{DM}$ digestibility, $\mathrm{pH}$ variation and $\mathrm{NH}_{3}-\mathrm{N}$ concentration as influenced by different feed treatments

\begin{tabular}{|c|c|c|c|c|c|c|c|c|c|c|}
\hline \multirow{3}{*}{ Item } & \multicolumn{6}{|c|}{ Treatment $^{1}$} & \multirow{3}{*}{ SEM $^{2}$} & \multirow{2}{*}{\multicolumn{3}{|c|}{ significance }} \\
\hline & \multicolumn{3}{|c|}{$\mathrm{C}$} & \multicolumn{3}{|c|}{$\mathrm{EC}$} & & & & \\
\hline & $S$ & ES & FS & $S$ & ES & FS & & $\mathrm{CT}^{4}$ & $\mathrm{ST}^{4}$ & $\mathrm{CT} \times \mathrm{ST}^{4}$ \\
\hline$\overline{\mathrm{SI}^{3}}$ & 0.85 & 0.95 & 0.71 & 0.93 & 0.8 & 0.72 & & & & \\
\hline \multicolumn{11}{|c|}{ DM digestibility (\%) } \\
\hline $0 \mathrm{~h}$ & $13.32^{\mathrm{a}}$ & $13.78^{\mathrm{a}}$ & $11.53^{\mathrm{b}}$ & $10.32^{\mathrm{b}}$ & $10.57^{\mathrm{b}}$ & $8.67^{\mathrm{c}}$ & 0.2048 & $* *$ & $* *$ & NS \\
\hline $3 \mathrm{~h}$ & $16.44^{\mathrm{a}}$ & $16.73^{\mathrm{a}}$ & $13.53^{\mathrm{b}}$ & $16.47^{\mathrm{a}}$ & $16.77^{\mathrm{a}}$ & $13.67^{\mathrm{b}}$ & 0.0793 & NS & $* *$ & NS \\
\hline $6 \mathrm{~h}$ & $20.93^{\mathrm{c}}$ & $21.94^{\mathrm{b}}$ & $17.26^{\mathrm{e}}$ & $22.49^{\mathrm{b}}$ & $24.01^{\mathrm{a}}$ & $18.39^{\mathrm{d}}$ & 0.1354 & $* *$ & $* *$ & NS \\
\hline $12 \mathrm{~h}$ & $31.00^{\mathrm{b}}$ & $32.27^{\mathrm{ab}}$ & $21.84^{\mathrm{d}}$ & $32.37^{\mathrm{ab}}$ & $33.73^{\mathrm{a}}$ & $24.31^{\mathrm{c}}$ & 0.2783 & $* *$ & $* *$ & NS \\
\hline $24 \mathrm{~h}$ & $47.78^{\mathrm{ab}}$ & $49.01^{\mathrm{a}}$ & $36.85^{\mathrm{d}}$ & $47.43^{\mathrm{b}}$ & $48.48^{\mathrm{ab}}$ & $40.35^{\mathrm{c}}$ & 0.2892 & $* *$ & $* *$ & $* *$ \\
\hline \multicolumn{11}{|l|}{$\mathrm{pH}$} \\
\hline $0 \mathrm{~h}$ & $7.17^{\mathrm{a}}$ & $7.15^{\mathrm{ab}}$ & $7.11^{\mathrm{b}}$ & $7.15^{\mathrm{ab}}$ & $7.14^{\mathrm{ab}}$ & $7.14^{\mathrm{ab}}$ & 0.0122 & NS & $*$ & NS \\
\hline $3 \mathrm{~h}$ & $7.08^{\mathrm{a}}$ & $7.04^{\mathrm{ab}}$ & $7.03^{\mathrm{ab}}$ & $6.91^{\mathrm{bc}}$ & $6.82^{\mathrm{c}}$ & $6.89^{\mathrm{bc}}$ & 0.0182 & $* *$ & NS & NS \\
\hline $6 \mathrm{~h}$ & $6.72^{\mathrm{a}}$ & $6.63^{\mathrm{a}}$ & $6.72^{\mathrm{a}}$ & $6.38^{\mathrm{b}}$ & $6.26^{\mathrm{b}}$ & $6.38^{\mathrm{b}}$ & 0.0215 & $* *$ & $* *$ & NS \\
\hline $12 \mathrm{~h}$ & $6.21^{\mathrm{b}}$ & $6.14^{\mathrm{b}}$ & $6.59^{\mathrm{a}}$ & $5.82^{\mathrm{c}}$ & $5.70^{\mathrm{c}}$ & $6.17^{\mathrm{b}}$ & 0.021 & $* *$ & $* *$ & NS \\
\hline $24 \mathrm{~h}$ & $5.39^{\mathrm{c}}$ & $5.35^{\mathrm{c}}$ & $5.74^{\mathrm{a}}$ & $5.37^{\mathrm{c}}$ & $5.37^{\mathrm{c}}$ & $5.47^{\mathrm{b}}$ & 0.0146 & $* *$ & $* *$ & $* *$ \\
\hline \multicolumn{11}{|c|}{$\mathrm{NH}_{3}-\mathrm{N}$ concentration $(\mathrm{mg} / 100 \mathrm{ml})$} \\
\hline $0 \mathrm{~h}$ & $3.69^{\mathrm{b}}$ & $3.83^{\mathrm{ab}}$ & $4.49^{\mathrm{a}}$ & $3.76^{\mathrm{ab}}$ & $4.13^{\mathrm{ab}}$ & $4.10^{\mathrm{ab}}$ & 0.1184 & NS & $* *$ & NS \\
\hline $3 \mathrm{~h}$ & $5.17^{\mathrm{b}}$ & $6.36^{\mathrm{a}}$ & $1.86^{\mathrm{c}}$ & $5.41^{\mathrm{b}}$ & $5.79^{\mathrm{ab}}$ & $2.09^{c}$ & 0.0952 & NS & $* *$ & $*$ \\
\hline $6 \mathrm{~h}$ & $6.13^{\mathrm{a}}$ & $8.23^{\mathrm{a}}$ & $0.51^{\mathrm{b}}$ & $7.43^{\mathrm{a}}$ & $8.23^{\mathrm{a}}$ & $1.81^{\mathrm{b}}$ & 0.3132 & $*$ & $* *$ & NS \\
\hline $12 \mathrm{~h}$ & $11.27^{\mathrm{a}}$ & $11.96^{\mathrm{a}}$ & $2.66^{\mathrm{c}}$ & $6.20^{\mathrm{b}}$ & $5.14^{\mathrm{b}}$ & $1.84^{\mathrm{c}}$ & 0.4907 & $* *$ & $* *$ & $* *$ \\
\hline $24 \mathrm{~h}$ & $27.09^{\mathrm{a}}$ & $27.81^{\mathrm{a}}$ & $4.38^{c}$ & $22.53^{\mathrm{b}}$ & $20.39^{b}$ & $5.36^{\mathrm{c}}$ & 0.7257 & $* *$ & $* *$ & $* *$ \\
\hline
\end{tabular}

${ }^{1} \mathrm{C}=$ Corn, EC = Enzyme treated corn, $\mathrm{S}=$ Soybean meal, ES = Enzyme treated soybean meal, FS = Formaldehyde treated soybean meal.

${ }^{2} \mathrm{SEM}=$ Standard error of the mean.

${ }^{3} \mathrm{SI}=$ Synchrony index. SI close to 1.0 means that ruminal release of protein and energy sources is balanced appropriately compared to those having lower SI.

* Significant at $\mathrm{p}<0.05$. ** Significant at $\mathrm{p}<0.01$. NS $=$ Not significant $(\mathrm{p}>0.05)$.

${ }^{4} \mathrm{CT}=$ The effect of $\mathrm{C}$ treatment, $\mathrm{ST}=$ The effect of $\mathrm{S}$ treatment and $\mathrm{CT} \times \mathrm{ST}=$ The interaction between $\mathrm{C}$ and $\mathrm{S}$ treatment

${ }^{a, b, c}$ Indicates significant difference within the same raw $(\mathrm{p}<0.05)$. 
most incubation times, with a more noticeable effect after 6 $\mathrm{h}$, but the interaction between the treatments was observed only at $24 \mathrm{~h}$ of incubation. EC-containing diets had a lower $(\mathrm{p}<0.05)$ ruminal $\mathrm{pH}$ than those with untreated $\mathrm{C}$ as the carbohydrate source at 6 and $12 \mathrm{~h}$ incubation, indicating that rumen microbes degrade EC more efficiently than $\mathrm{C}$. FS containing diets showed higher $(\mathrm{p}<0.01)$ ruminal $\mathrm{pH}$ irrespective of carbohydrate source after $6 \mathrm{~h}$ incubation.

The ammonia-N concentrations of CS, CES, ECS, and ECES diets increased as incubation progressed. Ammonia$\mathrm{N}$ concentration has been reported to increase immediately after feeding for 2 to $3 \mathrm{~h}$ and decrease until the next feeding in other in vivo studies (Chumpawadee et al., 2006; Seo et al., 2010). Our data showed the opposite result, with the above-mentioned in vivo ammonia-N concentration increasing consistently, which may be an indication of poor utilization of ammonia for MPS or may be due to decreased absorption of ammonia from the rumen as no absorption into the body is possible under in vitro conditions. We used a batch culture in vitro system in which the end product of fermentation could not flow out, and thus ammonia-N was overproduced and accumulated continuously. FS-containing diets had lower $(\mathrm{p}<0.01)$ ammonia-N content than $\mathrm{S}$ - and ES-containing diets at all incubation times. This suggests that FS was not degraded to a significant extent by ruminal microbes. At $12 \mathrm{~h}$ and $24 \mathrm{~h}$ of incubation, EC diets showed a lower $(\mathrm{p}<0.05)$ ammonia-N concentration than $\mathrm{C}$ containing diets, regardless the degree of synchronicity, indicating that efficient utilization of ammonia-N for MPS was achieved by ruminal microorganisms only when EC was offered as a carbohydrate source. The purine contents of all diets at $12 \mathrm{~h}$ of incubation were also confirmed the relationship between ammonia-N utilization and MPS, since the measurement of purine base production is an indirect method for evaluating MPS in the rumen (Makkar and Becker, 1999) (Table 5). Our data support the theory that lower ruminal $\mathrm{NH}_{3}-\mathrm{N}$ concentration correlates with higher utilization of $\mathrm{NH}_{3}-\mathrm{N}$ for MPS. There were no dietary treatment effects on purine base contents at $0 \mathrm{~h}$ of incubation. However, treatment effects of $\mathrm{C}$ and $\mathrm{S}$ and their interaction were significant $(\mathrm{p}<0.01)$ at $12 \mathrm{~h}$ of incubation (Table 5). When $\mathrm{C}$ was used as an energy source, purine base concentration increased as the diets were more synchronized; this effect was not observed when EC was an energy source. ECES had the highest $(p<0.01)$ purine base content of all the diets, although it had only intermediate synchronicity of energy and protein supply in the rumen. These data imply that the supply of a highly fermentable energy source, rather than the synchronicity of energy and protein supply, was a more influential factor for stimulating MPS from ammonia-N (Hoover and Stokes, 1991). Rotger et al. (2006) have also concluded that rumen fermentation may be more limited by carbohydrate or protein availability than by the degree of synchronicity. A sufficient energy supply from a rapidly fermentable carbohydrate source may allow for the efficient incorporation of peptides, free amino

Table 5. VFA and purine concentration as influenced by different feed treatments at $12 \mathrm{~h}$ incubation

\begin{tabular}{|c|c|c|c|c|c|c|c|c|c|c|}
\hline \multirow{3}{*}{ Item } & \multicolumn{6}{|c|}{ Treatment $^{1}$} & \multirow{3}{*}{ SEM $^{2}$} & \multirow{2}{*}{\multicolumn{3}{|c|}{ significance }} \\
\hline & \multicolumn{3}{|c|}{$\mathrm{C}$} & \multicolumn{3}{|c|}{$\mathrm{EC}$} & & & & \\
\hline & $S$ & ES & FS & $S$ & ES & FS & & $\mathrm{CT}^{4}$ & $\mathrm{ST}^{4}$ & $\mathrm{CT} \times \mathrm{ST}^{4}$ \\
\hline $\mathrm{SI}^{3}$ & 0.85 & 0.95 & 0.71 & 0.93 & 0.8 & 0.72 & & & & \\
\hline \multicolumn{11}{|c|}{ VFA concentration (mM) } \\
\hline Total & $81.77^{\mathrm{b}}$ & $87.22^{\mathrm{b}}$ & $63.78^{\mathrm{c}}$ & $97.21^{\mathrm{a}}$ & $103.20^{\mathrm{a}}$ & $85.44^{\mathrm{b}}$ & 1.506 & $* *$ & $* *$ & $* *$ \\
\hline Acetate & $41.06^{\mathrm{cd}}$ & $42.99^{\mathrm{bc}}$ & $33.59^{\mathrm{e}}$ & $44.61^{\mathrm{ab}}$ & $45.79^{\mathrm{a}}$ & $39.10^{\mathrm{d}}$ & 0.5146 & $* *$ & $* *$ & $* *$ \\
\hline Propionate & $25.48^{\mathrm{c}}$ & $28.04^{\mathrm{bc}}$ & $18.69^{\mathrm{d}}$ & $35.40^{\mathrm{a}}$ & $38.52^{\mathrm{a}}$ & $30.65^{\mathrm{b}}$ & 0.7316 & $* *$ & $* *$ & $* *$ \\
\hline Iso-butyrate & $0.93^{\mathrm{cd}}$ & $1.06^{\mathrm{bc}}$ & $0.69^{\mathrm{d}}$ & $1.34^{\mathrm{ab}}$ & $1.52^{\mathrm{a}}$ & $0.92^{\mathrm{cd}}$ & 0.0761 & $* *$ & $* *$ & $* *$ \\
\hline Butyrate & $12.05^{\mathrm{b}}$ & $12.77^{\mathrm{b}}$ & $9.14^{\mathrm{c}}$ & $13.46^{\mathrm{ab}}$ & $14.59^{\mathrm{a}}$ & $12.55^{\mathrm{b}}$ & 0.3423 & $* *$ & $* *$ & $* *$ \\
\hline Iso-Valerate & $1.24^{\mathrm{b}}$ & $1.30^{\mathrm{ab}}$ & $0.88^{\mathrm{d}}$ & $1.23^{\mathrm{b}}$ & $1.41^{\mathrm{a}}$ & $1.04^{\mathrm{c}}$ & 0.0295 & $* *$ & $* *$ & $* *$ \\
\hline Valerate & $1.01^{\mathrm{bc}}$ & $1.06^{\mathrm{b}}$ & $0.79^{\mathrm{c}}$ & $1.16^{\mathrm{ab}}$ & $1.33^{\mathrm{a}}$ & $1.18^{\mathrm{ab}}$ & 0.052 & $* *$ & $* *$ & $* *$ \\
\hline $\mathrm{A}: \mathrm{P}$ ratio & $1.61^{\mathrm{b}}$ & $1.53^{\mathrm{b}}$ & $1.8^{\mathrm{a}}$ & $1.26^{\mathrm{c}}$ & $1.19^{\mathrm{c}}$ & $1.28^{\mathrm{c}}$ & 0.0304 & $* *$ & $* *$ & $* *$ \\
\hline \multicolumn{11}{|c|}{ Purine base $(\mu \mathrm{g} / \mathrm{ml})$} \\
\hline $0 \mathrm{~h}$ & 9.13 & 9.17 & 8.94 & 8.92 & 8.88 & 8.82 & 0.1366 & NS & NS & NS \\
\hline $12 \mathrm{~h}$ & $30.09^{c}$ & $33.98^{\mathrm{b}}$ & $19.52^{\mathrm{e}}$ & $38.89^{\mathrm{a}}$ & $40.15^{\mathrm{a}}$ & $27.67^{\mathrm{d}}$ & 0.2923 & $* *$ & $* *$ & $* *$ \\
\hline $24 \mathrm{~h}$ & $33.92^{\mathrm{a}}$ & $33.42^{\mathrm{a}}$ & $29.11^{\mathrm{b}}$ & $27.86^{\mathrm{b}}$ & $27.09^{\mathrm{b}}$ & $26.70^{\mathrm{b}}$ & 0.7118 & $* *$ & $* *$ & $*$ \\
\hline
\end{tabular}

${ }^{1} \mathrm{C}=$ Corn, EC = Enzyme treated corn, $\mathrm{S}=$ Soybean meal, ES = Enzyme treated soybean meal, FS = Formaldehyde treated soybean meal.

${ }^{2} \mathrm{SEM}$ means standard error of the mean.

${ }^{3} \mathrm{SI}=$ Synchrony index. SI close to 1.0 means that ruminal release of protein and energy sources is balanced appropriately compared to those having lower SI.

* Significant at $\mathrm{p}<0.05$. ** Significant at $\mathrm{p}<0.01$. NS $=$ Not significant $(\mathrm{p}>0.05)$.

${ }^{4} \mathrm{CT}=$ The effect of $\mathrm{C}$ treatment, $\mathrm{ST}=$ The effect of $\mathrm{S}$ treatment and $\mathrm{CT} \times \mathrm{ST}=$ The interaction between $\mathrm{C}$ and $\mathrm{S}$ treatment

a, b, c, d, e Indicates significant difference within the same raw $(\mathrm{p}<0.05)$. 
acids, and/or ammonia-N into microbial cells, thereby reducing ammonia- $\mathrm{N}$ concentration in the rumen and increasing MP. Hristov et al. (1997) confirmed the effects of different levels of carbohydrate and ammonia availability on the utilization of ammonia and alpha-amino $\mathrm{N}$ by ruminal mixed microorganisms in vitro. They observed an increased uptake and incorporation of ammonia into microbial cells with increasing carbohydrate level regardless of the type of $\mathrm{N}$ compounds. Theoretically, synchronization of energy and $\mathrm{N}$ release in the rumen can increase MPS, $\mathrm{N}$ utilization, and rumen fermentation efficiency. However, rumen microorganisms can respond to a deficiency of nutrients by synthesizing intracellular storage polysaccharides when energy sources are abundant, or by utilizing cellular storage and recycled urea $\mathrm{N}$ when carbohydrate and $\mathrm{N}$ sources are scarce (Valkeners et al., 2004; Ichinohe and Fujihara, 2008).

The VFA concentrations for each treatment after $12 \mathrm{~h}$ of incubation are shown in Table 5. There were significant $C$ and $S$ treatment effects, and the interaction of effects on VFA concentrations was also significant. Similar to purine concentrations, total VFA production and individual VFA concentrations of the groups using EC as an energy source was higher $(\mathrm{p}<0.01)$ than in other groups $(\mathrm{CS}, \mathrm{CES}$ and CFS). These parameters were not affected by the degree of synchronicity, as was seen with the purine base concentrations. All mixtures containing ECES had the highest values than any other treatments, in spite of having an intermediate SI value.

In summary, synchronization had positive effects on rumen fermentation, DM digestibility, and MPS when these were compared between low synchronous (CFS, ECFS) versus intermediate (CS, ECES) or high synchronous feeds (CES, ECS). However, there were no consistent results when we compared rumen fermentation characteristics between intermediate and high synchronous feeds. Meanwhile, rapidly fermentable energy and protein sources showed higher DM digestibility, VFA production, ammonia-N utilization, and purine base contents, indicating that the availability of energy or the protein source should be also considered as the other important factor for improving rumen fermentation and MPS.

\section{ACKNOWLEDGEMENTS}

This study was carried out with the support of the Cooperative Research Program for Agricultural Science and Technology Development (Project No. 20090101-030-166001-03-00), Rural Development Administration, Korea.

\section{REFERENCES}

Aldrich, J. M., L. D. Muller, G. A. Varga and L. C. Griel Jr. 1993.
Nonstructural carbohydrate and protein effects on rumen fermentation, nutrient flow, and performance of dairy cows. J. Dairy Sci. 76:1091-1105.

AOAC. 1990. Official methods of analysis. 15th ed. Association of Official Analytical Chemists, A., VA, USA.

Chaney, A. L. and E. P. Marbach. 1962. Modified reagent for determination of urea and ammonia. Clin. Chem. 8:130-132.

Chumpawadee, S., K. Sommart, T. Vongpralub and V. Pattarajinda. 2006. Effects of synchronizing the rate of dietary energy and nitrogen release on ruminal fermentation, microbial protein synthesis, blood urea nitrogen and nutrient digestibility in beef cattle. Asian-Aust. J. Anim. Sci. 19:181-188.

Cole, N. A. and R. W. Todd. 2008. Opportunities to enhance performance and efficiency through nutrient synchrony in concentrate-fed ruminants. J. Anim. Sci. 86:E318-333.

Dewhurst, R. J., D. R. Davies and R. J. Merry. 2000. Microbial protein supply from the rumen. Anim. Feed Sci. Technol. 85:121.

Eghbali, M., F. Kafilzadeh, F. Hozhabri, S. Afshar and M. KazemiBonchenari. 2011. Treating canola meal changes in situ degradation, nutrient apparent digestibility, and protein fractions in sheep. Small Rumin. Res. 96:136-139.

Erwin, W. S., G. J. Marco and E. M. Emery. 1961. Volatile fatty acid analysis of blood and rumen fluids by gas chromatography. J. Dairy Sci. 44:1768-1771.

George, S. K., M. T. Dipu, U. R. Mehra, P. Singh, A. K. Verma and J. S. Ramgaokar. 2006. Improved HPLC method for the simultaneous determination of allantoin, uric acid and creatinine in cattle urine. J. Chromatogr. B 832:134-137.

Herrera-Saldana, R., R. Gomez-Alarcon, M. Torabi and J. T. Huber. 1990. Influence of synchronizing protein and starch degradation in the rumen on nutrient utilization and microbial protein synthesis. J. Dairy Sci. 73:142-148.

Hoover, W. H. and S. R. Stokes. 1991. Balancing Carbohydrates and proteins for optimum rumen microbial yield. J. Dairy Sci. 74:3630-3644.

Hristov, A. N., T. A. McAllister and K. J. Cheng. 1997. Effect of carbohydrate level and ammonia availability on utilization of alpha amino nitrogen by mixed ruminal microorganisms in vitro. Proc. Western Section Am. Soc. Anim. Sci. 48:186-189.

Ichinohe, T. and T. Fujihara. 2008. Adaptive changes in microbial synthesis and nitrogen balance with progressing dietary feeding periods in sheep fed diets differing in their ruminal degradation synchronicity between nitrogen and organic matter. Anim. Sci. J. 79:322-331.

Makkar, H. P. and K. Becker. 1999. Purine quantification in digesta from ruminants by spectrophotometric and HPLC methods. Br. J. Nutr. 81:107-112.

McDougall, E. I. 1948. Studies on ruminant saliva. 1. The composition and output of sheep's saliva. Biochem. J. 43:99109.

National Research Council. 2000. Nutrient requirement of dairy cattle. $7^{\text {th }}$ ed. Natl. Acad. Press, Washington, DC, USA.

Nocek, J. E. and J. B. Russell. 1988. Protein and energy as an integrated system. Relationship of ruminal protein and carbohydrate availability to microbial synthesis and milk production. J. Dairy Sci. 71:2070-2107.

Ørskov, E. R. and I. McDonald. 1979. The estimation of protein degradability in the rumen from incubation measurements 
weighted according to rate of passage. J. Agric. Sci. 92:499503.

Ørskov, E. R., F. DeB Hovell and F. Mould. 1980. The use of nylon bag technique for the evaluation of feedstuffs. Trop. Anim. Prod. 5:195-212.

Richardson, J. M., R. G. Wilkinson and L. A. Sinclair. 2003. Synchrony of nutrient supply to the rumen and dietary energy source and their effects on the growth and metabolism of lambs. J. Anim. Sci. 81:1332-1347.

Rotger, A., A. Ferret, S. Calsamiglia and X. Manteca. 2006. Effects of nonstructural carbohydrates and protein sources on intake, apparent total tract digestibility, and ruminal metabolism in vivo and in vitro with high-concentrate beef cattle diets. J. Anim. Sci. 84:1188-1196.

SAS. 1996. SAS User's Guide: Statistics, Version $6.12^{\text {th }}$ ed. SAS Inst. Inc. Cary, NC, USA.

Seo, J. K., J. Y. Yang, H. J. Kim, S. D. Upadhaya, W. M. Cho and J. K. Ha. 2010. Effects of synchronization of carbohydrate and protein supply on ruminal fermentation, nitrogen metabolism and microbial protein synthesis in Holstein steers. Asian-Aust. J. Anim. Sci. 23:1455-1461.

Shabi, Z., A. Arieli, I. Bruckental, Y. Aharoni, S. Zamwel, A. Bor and H. Tagari. 1998. Effect of the synchronization of the degradation of dietary crude protein and organic matter and feeding frequency on ruminal fermentation and flow of digesta in the abomasum of dairy cows. J. Dairy Sci. 81:1991-2000.

Sinclair, L. A., P. C. Garnsworthy, J. R. Newbold and P. J. Buttery. 1993. Effect of synchronizing the rate of dietary energy and nitrogen release on rumen fermentation and microbial protein synthesis in sheep. J. Agric. Sci. 120:251-263.
Valkeners, D., A. Thewis, F. Piron and Y. Beckers. 2004. Effect of imbalance between energy and nitrogen supplies on microbial protein synthesis and nitrogen metabolism in growing doublemuscled Belgian Blue bulls. J. Anim. Sci. 82:1818-1825.

Van Soest, P. J., J. B. Robertson and B. A. Lewis. 1991. Methods for dietary fiber, neutral detergent fiber, and non starch polysaccharides in relation to animal nutrition. J. Dairy Sci. 74:3583-3597.

Witt, M. W., L. A. Sinclair, R. G. Wilkinson and P. J. Buttery. 1999a. The effects of synchronizing the rate of dietary energy and nitrogen supply to the rumen on the production and metabolism of sheep: food characterization and growth and metabolism of ewe lambs given food ad libitum. Anim. Sci. 69:223-235.

Witt, M. W., L. A. Sinclair, R. G. Wilkinson, P. J. Buttery. 1999b. The effects of synchronizing the rate of dietary energy and nitrogen supply to the rumen on the metabolism and growth of ram lambs given food at a restricted level. Anim. Sci. 69:627636.

Witt, M. W., L. A. Sinclair, R. G. Wilkinson and P. J. Buttery. 2000. The effects of synchronizing the rate of dietary energy and nitrogen supply to the rumen on milk production and metabolism of ewes offered grass silage based diets. Anim. Sci. 71:187-195.

Zinn, R. A. and F. N. Owens. 1986. A rapid procedure for purine measurement and its use for estimating net ruminal protein synthesis. Can. J. Anim. Sci. 66:157-166. 